\title{
The influence of lamb rearing system on ewe milk and lamb growth traits in dairy sheep
}

\author{
M. Margetín ${ }^{1,2}$, M. Oravcová1,3, J. Margetínová1, K. Vavrišínová ${ }^{\text {and M. Janíček }}{ }^{2}$ \\ ${ }^{1}$ NAFC-RIAP Nitra, 95141 Lužianky, Slovak Republic \\ ${ }^{2}$ Slovak University of Agriculture in Nitra, 94976 Nitra, Slovak Republic
}

KEY WORDS: ewes, milk composition, milk
yield, lambs, growth rate, weaning systems

Received: $\quad 6$ May 2019

Revised: 31 October 2019

Accepted: 20 February 2020

${ }^{3}$ Corresponding author:

e-mail: marta.oravcova@nppc.sk

\begin{abstract}
The objectives were to analyse ewe milk and lamb growth traits of Slovak Dairy sheep breed. Three lamb rearing systems were formed, i.e., ARM2: ewes milked twice daily throughout a whole lactation, lambs fed with milk replacer almost from birth to weaning; TRM1: ewes milked once daily and suckled by lambs in pre-weaning period; TRM0: ewes exclusively suckled by lambs in pre-weaning period. After weaning, all ewes were milked twice daily. General linear models were used for analyses of ewe daily/cumulative milk yields, fat, protein and lactose percentages/yields, usable dry matter yields and somatic cell scores in pre-weaning, post-weaning and lactation periods, and lamb live weights at birth/selected ages and their daily gains from birth to weaning. Lamb rearing system, ewe parity/age and litter size were considered as fixed factors. Additionally, lamb sex was included in growth analyses. The significantly highest cumulative milk yield was found in ARM2 ewes (202 \pm 7 l); lower yield (by 17 and $64 \mathrm{I})$ was found in TRM1 and TRM0 ewes, respectively. In pre-weaning period, fat percentage and yield were significantly lower in TRM1 ewes $(2.75 \pm 0.14 \%$ and $0.85 \pm 0.12 \mathrm{~kg})$ than in ARM2 ewes $(4.40 \pm 0.13 \%$ and $2.76 \pm 0.12 \mathrm{~kg})$ as lamb contact makes ewes to with hold certain amounts of milk and fat in alveoli while machine milking to remain for offspring. No significant differences in daily gains among TRM1, TRM0 and ARM2 lambs were found $(0.260 \pm 0.007$, $0.277 \pm 0.006$ and $0.259 \pm 0.008 \mathrm{~kg}$, respectively). Summarizing, without negative effect on lamb growth, TRM1 system seems to be the most appropriate.
\end{abstract}

\section{Introduction}

Dairy sheep is a traditional branch of livestock in countries of Central and East Europe including Slovakia. In recent years, possibilities to improve milking ability traits that influence profitability of dairy sheep sector were investigated (Mačuhová et al., 2012; Antonič et al., 2013; Krupová et al., 2014). Purebred mating and breeding values prediction (Oravcová et al., 2005; 2015) contributed to the increase in milk production of local breeds (Tsigai, Improved Valachian). Besides, highly productive dairy breeds (Lacaune, East Friesian) helped to develop a recently recognised composite breed - Slovak Dairy sheep, which produces more milk than purebred local breeds (Margetín et al., 2013a;b). With respect to further increase of revenues from milk, possibilities how to optimise lamb rearing systems in dairy sheep are searched. Main goals are: more milk (mainly before lamb weaning) sold and no lamb growth intensity decreased. The latter is economically important due to fact that lambs share about $30 \%$ proportion of total revenues from dairy ewes (Krupová et al., 2014).

Lambs suckling ewe milk and weaned from 40 to 60 days of age represent a traditional rearing system, predominantly applied in Slovakia and 
neighbouring countries. Highly productive ewes are able to produce more milk than suckling lambs need for their growth (McKusick et al., 2001; Thomas et al., 2014). However, rearing systems with lambs enabled to suckle ewes either exclusively or partially prior to exclusive machine milking occur occasionally (Marnet and McKusick, 2001); in spite of fact that about 25 to $30 \%$ proportion of milk yield is produced during first 30 to 60 days of lactation (Folman et al., 1966; Dikmen et al., 2007). It was indicated that lamb rearing systems with ewes milked only after lambs are weaned decrease milk yield and reduce flock profitability (Gargouri et al., 1993; McKusick et al., 2001).

In an effort to maximize amount of milk which can be sold, various lamb rearing systems could be applied (Papachristoforou, 1990; Gargouri et al., 1993; McKusick et al., 2001; Dikmen et al., 2007). Besides artificially raised lambs on milk replacer, diet with ewes exclusively milked almost from the beginning of lactation and traditionally raised lambs suckling ewe milk (weaned from 30 to 60 days of age) with ewes milked only in post-weaning period, mixed lamb rearing systems with lambs enabled to suckle ewes and ewes milked in pre-weaning period were introduced (Knight et al., 1993; Dikmen et al., 2007). Changes in flock profitability were found when ewes were milked in pre-weaning period, i.e., more milk could be sold, while growth intensity of lambs remained unaffected (McKusick et al., 2001).

Increasing milk yield in dairy ewes, i.e., daily milk yield of about $1500 \mathrm{ml}$ in most productive individuals has been reported for last twenty years (Margetín et al., 1995; 1996). Variant lamb rearing systems and their impact on ewe milk and lamb growth traits in Slovakia have not been studied until now.

Therefore, the objectives of this study were to analyse ewe milk yield and composition traits in pre-weaning, post-weaning and lactation period, respectively, and lamb growth traits in dependence on lamb rearing system: (1) system in which lambs are fed with milk replacer, (2) system in which lambs suckle ewes in part and (3) system in which lambs suckle ewes exclusively in pre-weaning period. Ewes and lambs of Slovak Dairy sheep breed were included in the experiment.

\section{Material and methods}

\section{Animals and lamb rearing systems}

The data were gathered at the farm of NAFC - Research Institute for Animal Production Nitra located in North-West Slovakia in 2017.
Table 1. Data structure, ewe prolificacy and lamb mortality in dependence on lamb rearing system

\begin{tabular}{lcccc}
\hline Indices & ARM2 $^{1}$ & TRM1 $^{2}$ & TRM0 $^{3}$ & Total \\
\hline Number of ewes, heads & 32 & 39 & 42 & 113 \\
Number of lambs born alive, & 40 & 57 & 57 & 154 \\
heads & 125 & 146 & 136 & 136 \\
Ewe prolificacy, \% & 1 & 0 & 1 & 2 \\
Lamb mortality, heads & 39 & 57 & 56 & 152 \\
Number of lambs, heads &
\end{tabular}

${ }^{1}$ ewes milked twice daily throughout a whole lactation; ${ }^{2}$ ewes milked once daily in pre-weaning period and twice daily in post-weaning period; ${ }^{3}$ ewes milked twice daily only in post-weaning period

A total, 113 ewes and 152 lambs of Slovak Dairy sheep were included in the experiment (Table 1) that was designed with respect to ewe age, litter size and lamb sex. Slovak Dairy sheep is a composite breed which has been formed through mating between local breeds (Tsigai and Improved Valachian) and highly productive breeds (Lacaune and East Friesian) since the 90s of the last century and which has become the most numerous dairy sheep population (Margetín et al., 2017). Shortly after delivering lambs, ewes were divided into three groups. First, ewes (32 heads) were machine milked twice daily (6:30 and 18:30) almost throughout a whole lactation (ARM2); lambs (39 heads) were separated from ewes and fed with commercial milk replacer. Second, ewes (39 heads) were machine milked once daily at 6.30 in pre-weaning period and twice daily in post-weaning period (TRM1); lambs (57 heads) were allowed to join ewes and suckle milk in daily hours (Margetín et al., 2010). Third, ewes (42 heads) were machine milked twice daily only after lambs were weaned (TRM0); lambs (56 heads) suckled ewe milk in pre-weaning period.

\section{Lamb and ewe diets and housing}

Lambs of ARM2 lamb rearing system were fed with commercial milk replacer which consisted of $50 \%$ of dried whey and $22 \%$ of refined vegetable oil ( $22.5 \%$ of nitrogenous substances, $0.1 \%$ of crude fibre and $7.5 \%$ of ash). A standard quality lucernegrass hay and additional feed mixture $(18 \%$ of nitrogenous substances, $2.4 \%$ of fat, $4 \%$ of crude fibre and $4 \%$ of ash) were available ad libitum almost from the beginning of the experiment. Lambs were weaned at the age of about 50 days.

Lambs of TRM1 lamb rearing system were kept in nurseries for night (Margetín et al., 2010) and enabled to suckle ewe milk for limited daily time. Lambs were weaned at the age of about 55 days. 
Lambs of TRM0 lamb rearing system were treated in nurseries, in the same way as TRM1 lambs; however, ewes were not milked in preweaning period and a whole amount of ewe milk was available for lambs. Lambs were weaned at the age of about 58 days.

In addition to ewe milk, TRM1 and TRM0 lambs were fed with the same standard quality lucerne-grass hay and with the same additional feed mixture (ad libitum) as ARM2 lambs.

Ewes were housed and fed in the same way (to avoid any feeding effect on milk yield), regardless of lamb rearing system. Ewe feed mixture consisted of lucerne-grass hay, maize silage and concentrates (NEL, i.e., netto energy of lactation equalled to 6.6 MJ; it comprises $15 \%$ of nitrogenous substances, $8 \%$ of crude fibre, $2.2 \%$ of fat and $3.3 \%$ of ash).

\section{Milking of ewes, milk yield and milk composition performance recording}

In winter, ARM2 and TRM1 ewes were milked in a small rotary parlour with 12 stalls (MILKOVIS, Valašská Bystřice, Czech Republic). In spring/summer, ewes of all three systems were milked in a lowline parlour with 24 stalls (FARMTEC, Jistebnice, Czech Republic). Milking machines of both parlours were set to provide 160 pulsations per minute (50:50 ratio and vacuum level of $39 \mathrm{kPa}$ ). Test-day milk yields were measured weekly (in pre-weaning period or up to corresponding early age of lambs) and monthly (in post-weaning period) using certified milkometers and were performed by authorised persons of Breeding Services (Bratislava, Slovak Republic); milk composition percentages (fat, protein and lactose) and somatic cell count (SCC) of each test-day sample were determined in the certified laboratory of Breeding Services (Bratislava, Slovak Republic). To avoid non-normal distribution of SCC (Barillet et al., 2001), somatic cell score (SCS) was calculated: $\mathrm{SCS}=\ln (\mathrm{SCC} / 100000+3)$.

Regardless of lactation phase, daily milk yield was calculated as sum of machine and stripped milk. The difference between TRM1 and ARM2 ewes in pre-weaning period was as follows: daily milk yield referred to morning milking yield (TRM1 ewes) or daily milk yield referred to sum of morning and evening milkings (ARM2 ewes) taking into account AC method (as defined by ICAR, 2014). In postweaning period, daily milk yield referred to sum of morning and evening milkings taking into account AC method (as defined by ICAR, 2014). Daily milk fat, protein and usable dry matter (defined as sum of: milk fat and protein yields) yields were calculated taking into account fat and protein percentages and daily milk yield according to ICAR (2014).

Regardless of lactation phase, total (cumulative) milk yield was calculated using Fleischmann method (ICAR, 2014) separately for pre-weaning and post-weaning period, respectively. Total lactation (cumulative) milk yield referred to sum of total (cumulative) milk yield in pre-weaning period and total (cumulative) milk yield in post-weaning period, except for total (cumulative) milk yield of TRM0 ewes which referred only to post-weaning period. Total (cumulative) milk composition yields were similarly calculated. Fat, protein and lactose percentages as well as SCS throughout respective lactation phases were also calculated.

\section{Ewe prolificacy and lamb growth measurements}

Ewe prolificacy was $136 \%$ on average (Table 1). There were 78 males and 74 females included in the experiment. With respect to litter size, $39 \%$ were single-lamb litters and $61 \%$ were multiple litters. Lambs were weighed at birth and at each test-day milk measurement before weaning (in addition, about 7-day old lambs were weighed). The last weight was measured at weaning. Test-day weight measurements were used to adjust for 10, 20, 30 and 40 days of age (Table 1 ). Average daily gains were calculated as differences between weights at weaning and birth.

\section{Statistical evaluation}

Analyses of variance for ewe milk and lamb growth traits were performed (General Linear Model procedure of SAS ver. 9.2 software; SAS Institute Inc. (2009)). The models for total (cumulative), i.e., commercial milk yields, fat, protein and lactose percentages, SCS and fat, protein and usable dry matter yields in pre-weaning, post-weaning and lactation period, respectively, included the following fixed effects: lamb rearing system (ARM2, TRM1 and TRM0), parity (1, 2, 3, 4 and 5+) and litter size (single- and multiple-lamb births). The models for daily milk yields, and daily fat, protein and lactose percentages as well as SCS were analysed separately for respective lactation days and included the same fixed effects.

Lamb growth traits were analysed using the models with the following fixed effects: lamb rearing system (ARM0, TRM1 and TRM2), lamb sex (male and female), litter size (single- and multiple-lamb litters) and ewe age $(2,3,4,5$ and $6+$ corresponding with parity 1, 2, 3, 4 and 5+). 
Statistical significances of fixed effects were tested by Fischer F-test; statistical differences between individual levels were tested by post-hoc Scheffe's multiple range tests. The significance was set to $P<0.05$.

\section{Results}

\section{Milk yield and milk composition traits}

In pre-weaning period, TRM1 ewes were milked 5 days longer $(55 \pm 0.20$ vs $50 \pm 0.30$ days, $P<0.05)$ than ARM2 ewes (Table 2). Average daily and total (cumulative) pre-weaning milk yield in ARM2 ewes were about two times higher than those in TRM1 ewes $(P<0.01)$. Fat percentage in ARM2 ewes was by 47 percentage points higher than in TRM1 ewes $(P<0.01)$, while lactose percentage in ARM2 ewes was by 5 percentage points lower than in TRM1 ewes $(P<0.05)$. No significant differences in protein percentage and in SCS were found between ARM2 and TRM1 ewes. With respect to milk composition yields, these were found significantly higher $(P<0.01)$ in ARM2 ewes than in TRM1 ewes: fat yield, protein yield and usable dry matter yield, respectively.

Table 2. Milk yield and milk composition in pre-weaning period in dependence on lamb rearing system

\begin{tabular}{|c|c|c|}
\hline \multirow[b]{2}{*}{ Traits } & \multicolumn{2}{|c|}{ Lamb rearing system } \\
\hline & $\begin{array}{l}\overline{\text { ARM21 }} \\
(n=32)\end{array}$ & $\begin{array}{l}\text { TRM1 }^{2} \\
(n=39)\end{array}$ \\
\hline Length of pre-weaning period, days & $50 \pm 0.30^{a}$ & $55 \pm 0.20^{b}$ \\
\hline Total milk yield, I & $66 \pm 7^{\mathrm{A}}$ & $28 \pm 6^{B}$ \\
\hline Daily milk yield, ml/day & $1167 \pm 37^{A}$ & $511 \pm 32^{B}$ \\
\hline Fat percentage, $\%$ & $4.40 \pm 0.13^{a}$ & $2.75 \pm 0.14^{b}$ \\
\hline Protein percentage, $\%$ & $4.84 \pm 0.07$ & $4.88 \pm 0.07$ \\
\hline Lactose percentage, $\%$ & $4.79 \pm 0.04^{\mathrm{a}}$ & $5.01 \pm 0.04^{b}$ \\
\hline Somatic cell score & $4.20 \pm 0.29$ & $3.63 \pm 0.28$ \\
\hline Fat yield, $\mathrm{kg}$ & $2.76 \pm 0.12^{\mathrm{A}}$ & $0.85 \pm 0.12^{\mathrm{B}}$ \\
\hline Protein yield, $\mathrm{kg}$ & $2.99 \pm 0.12^{\mathrm{A}}$ & $1.59 \pm 0.12^{\mathrm{B}}$ \\
\hline Usable dry matter yield, $\mathrm{kg}$ & $5.75 \pm 0.24^{\mathrm{A}}$ & $2.44 \pm 0.32^{\mathrm{B}}$ \\
\hline
\end{tabular}

In analyses regarding post-weaning period (Table 3), no significant differences were found in average daily milk yield (values between $855 \pm 23$ and $910 \pm 27 \mathrm{ml}$ ) and in total (cumulative) post-weaning milk yield among three lamb rearing systems. No significant differences were also found in fat percentage and in SCS. Contrariwise, significant differences were found in protein percentage (between ARM2 and TRM0 ewes, $P<0.05)$ and in lactose percentage (between ARM2 and TRM0 ewes, and between
Table 3. Milk yield and milk composition in post-weaning period in dependence on lamb rearing system

\begin{tabular}{|c|c|c|c|}
\hline \multirow[b]{2}{*}{ Traits } & \multicolumn{3}{|c|}{ Lamb rearing system } \\
\hline & $\begin{array}{l}\text { ARM21 } \\
(n=32)\end{array}$ & $\begin{array}{l}\text { TRM12 }^{2} \\
(n=39)\end{array}$ & $\begin{array}{l}\text { TRMO }^{3} \\
(n=42)\end{array}$ \\
\hline $\begin{array}{l}\text { Length of post-weaning } \\
\text { period, days }\end{array}$ & 147 & 147 & $147 \pm 0.10$ \\
\hline Total milk yield, I & $142 \pm 14$ & $148 \pm 11$ & $138 \pm 5$ \\
\hline Daily milk yield, ml/day & $910 \pm 27$ & $891 \pm 24$ & $855 \pm 23$ \\
\hline Fat percentage, $\%$ & $7.37 \pm 0.15$ & $7.32 \pm 0.14$ & $7.68 \pm 0.13$ \\
\hline Protein percentage, $\%$ & $5.41 \pm 0.08^{\mathrm{a}}$ & $5.62 \pm 0.07^{a b}$ & b $5.80 \pm 0.07^{b}$ \\
\hline Lactose percentage, $\%$ & $4.61 \pm 0.03^{a}$ & $4.50 \pm 0.03^{\mathrm{a}}$ & $4.93 \pm 0.03^{b}$ \\
\hline Somatic cell score & $3.98 \pm 0.28$ & $3.76 \pm 0.26$ & $4.16 \pm 0.25$ \\
\hline Fat yield, kg & $10.51 \pm 0.42$ & $11.21 \pm 0.39$ & $10.84 \pm 0.37$ \\
\hline Protein yield, $\mathrm{kg}$ & $7.70 \pm 0.33$ & $8.62 \pm 0.31$ & $8.20 \pm 0.29$ \\
\hline Usable dry matter yield, $\mathrm{kg}$ & $\mathrm{g} 18.26 \pm 0.74$ & $19.83 \pm 0.68$ & $19.05 \pm 0.65$ \\
\hline \multicolumn{4}{|c|}{$\begin{array}{l}{ }^{1} \text { ewes milked twice throughout a whole lactation; }{ }^{2} \text { ewes milked once } \\
\text { daily in pre-weaning period and twice daily in post-weaning period; } \\
{ }^{3} \text { ewes milked twice daily only in post-weaning period; } n \text { - number of } \\
\text { ewes; } ; \text { a,b - least squares means with different subscription within each } \\
\text { trait differ at } P<0.05\end{array}$} \\
\hline
\end{tabular}

TRM1 and TRM0 ewes, $P<0.05$ for both comparisons). With respect to milk composition yields, no statistical differences were found.

In analyses regarding lactation milk traits (Table 4), differences between TRM0 ewes on one hand and ARM2 as well as TRM1 ewes on the other hand increased due to fact that lactation traits in TRM0 ewes were identical with post-weaning period, while lactation period in ARM2 and TRM1 ewes referred to sum of pre-weaning and postweaning periods. Lactation length was about 8 days longer in TRM1 ewes than in ARM2 ewes; $P<0.05$ ).

Table 4. Total lactation milk yield and milk composition in dependence on lamb rearing treatment

\begin{tabular}{|c|c|c|c|}
\hline \multirow[b]{2}{*}{ Traits } & \multicolumn{3}{|c|}{ Lamb rearing system } \\
\hline & $\begin{array}{l}\text { ARM21 } \\
(n=32)\end{array}$ & $\begin{array}{l}\text { TRM1 }^{2} \\
(\mathrm{n}=39)\end{array}$ & $\begin{array}{l}\text { TRM0 }^{3} \\
(n=42)\end{array}$ \\
\hline Length of lactation, days & $199 \pm 0.20^{a}$ & $207 \pm 0.20^{b}$ & $147 \pm 0.10^{c}$ \\
\hline Total milk yield, I & $202 \pm 7^{a}$ & $185 \pm 7^{b}$ & $138 \pm 6^{c}$ \\
\hline Daily milk yield, ml/day & $1014 \pm 32^{\mathrm{a}}$ & $887 \pm 31^{b}$ & $855 \pm 30^{b}$ \\
\hline Fat percentage, $\%$ & $6.43 \pm 0.14^{\mathrm{a}}$ & $6.46 \pm 0.13^{a}$ & $7.67 \pm 0.13^{b}$ \\
\hline Protein percentage, $\%$ & $5.21 \pm 0.08^{a}$ & $5.48 \pm 0.07^{b}$ & $5.80 \pm 0.07^{c}$ \\
\hline Lactose percentage, $\%$ & $4.70 \pm 0.03^{\mathrm{a}}$ & $4.49 \pm 0.03^{b}$ & $4.50 \pm 0.03^{b}$ \\
\hline Somatic cell score & $4.05 \pm 0.28$ & $3.70 \pm 0.26$ & $4.16 \pm 0.25$ \\
\hline Fat yield, kg & \multicolumn{3}{|c|}{$13.29 \pm 0.47^{\mathrm{a}} 12.13 \pm 0.44^{\mathrm{a}} 10.83 \pm 0.42^{\mathrm{b}}$} \\
\hline Protein yield, $\mathrm{kg}$ & \multicolumn{2}{|c|}{$10.76 \pm 0.39^{\mathrm{a}} 10.26 \pm 0.36^{\mathrm{a}}$} & $8.21 \pm 0.34^{b}$ \\
\hline \multicolumn{4}{|c|}{ Usable dry matter yield, $\mathrm{kg} 24.86 \pm 0.85^{\mathrm{a}} 22.40 \pm 0.79^{\mathrm{a}} 19.04 \pm 0.72^{\mathrm{b}}$} \\
\hline \multicolumn{4}{|c|}{$\begin{array}{l}{ }^{1} \text { ewes milked twice daily throughout a whole lactation; }{ }^{2} \text { ewes milked } \\
\text { once daily in pre-weaning period and twice daily in post-weaning } \\
\text { period; }{ }^{3} \text { ewes milked twice daily only in post-weaning period; } \\
n \text { - number of ewes; a,b,c - least squares means with different subscrip- } \\
\text { tion within each trait differ at } P<0.05\end{array}$} \\
\hline
\end{tabular}


Both values significantly differed from lactation length of TRM0 ewes. With respect to average daily milk yields, these showed significant differences $(P<0.05)$ between ARM2 ewes on one hand, and TRM1 as well as TRM0 ewes on the other hand. Total commercial milk yield was found significantly higher $(P<0.05)$ in ARM2 ewes than in TRM1 ewes. When comparing to TRM0 ewes, differences in total cumulative milk yields between TRM0 and ARM2 as well as between TRM0 and TRM1 ewes increased $(P<0.05)$. Total commercial milk yield in TRM0 ewes represented 68 and $75 \%$ of those in ARM 2 and TRM1 ewes, respectively. The highest fat percentage was in TRM0 ewes; this significantly $(P<0.05)$ differed from ARM2 and TRM1 ewes. Similar pattern in protein percentages was found. The only exception, in comparison to fat percentages, were statistical differences $(P<0.05)$ in protein percentages among all lamb rearing systems analysed. Lactose percentage was the highest in ARM0 ewes and significantly $(P<0.05)$ differed from lactose percentages found in TRM1 and TRM0 ewes. No significant differences were found in SCS. When comparing lactation fat, protein and usable dry matter yields,
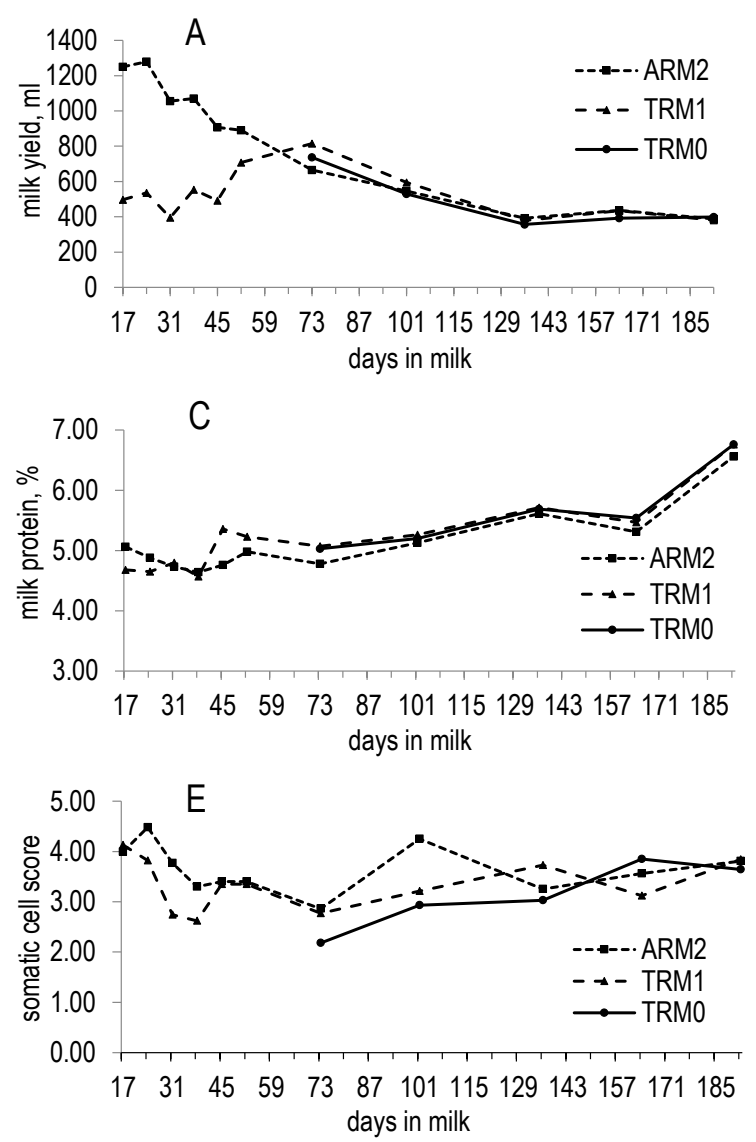

these were higher in ARM2 and TRM1 ewes and significantly differed $(P<0.05)$ from these yields in TRM0 ewes.

Daily milk yield, daily milk composition percentages as well as SCS over lactation (ARM2 and TRM1 ewes over pre-weaning and post-weaning periods; TRM0 ewes only over post-weaning period) are shown in Figure 1. Before weaning, significantly higher $(P<0.05)$ daily milk yields in ARM2 ewes than in TRM1 ewes were found (at 17, 24, 31, 38, 45 and 52 day, respectively). Fat percentages in pre-weaning period were also found significantly higher $(P<0.05)$ in ARM2 ewes than in TRM1 ewes. When comparing trends in fat percentages between ARM2 and TRM1 ewes (in pre-weaning period), these are not in agreement with expectations due to fact that higher fat percentages corresponded with higher daily milk yields, not vice versa. Protein percentages, lactose percentages and SCS varied to a smaller extent (protein percentages significantly differed with exception of day 38 , lactose percentages differed at 17,31 and 45 day of lactation and SCS differed only at day 38 .
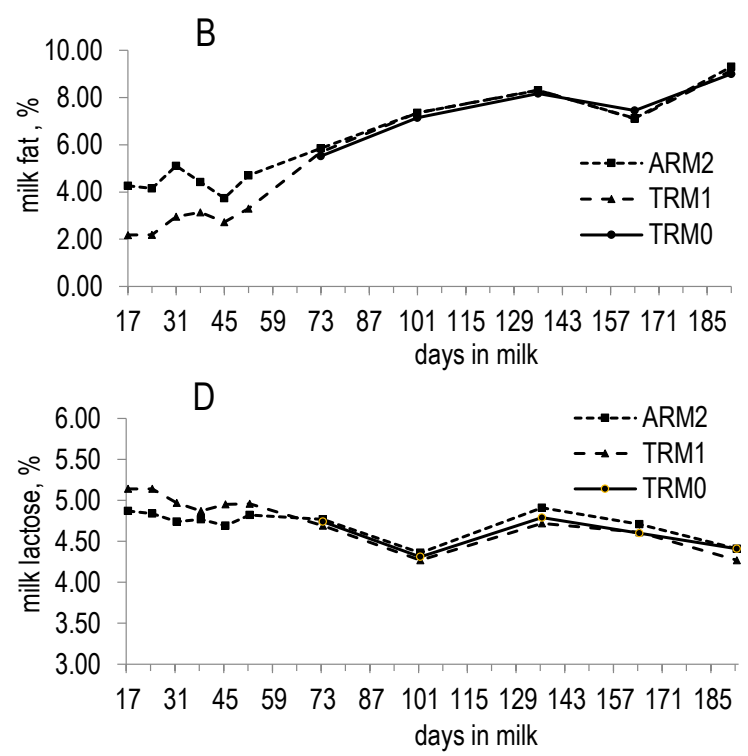

Figure 1. Daily milk yields (A), fat, protein and lactose percentages (B, $C$ and $D$, respectively), and somatic cell scores (E) in dependence on lamb rearing system: ARM2 - ewes milked twice daily throughout a whole lactation $(\mathbf{\square}, n=32)$, TRM1 - ewes milked (and suckled) once daily in pre-weaning period and twice daily in post-weaning period $(\boldsymbol{\Lambda}, n=39)$, and TRM0 - ewes suckled in pre-weaning period and milked twice daily in post-weaning period $(\bullet, n=42)$ 


\section{Lamb growth traits}

No significant differences in live weights at birth, and at day 10 and 40 were found in dependence on lamb rearing system (Table 5). With respect to remaining ages, the highest live weights were mostly found in TRM0 lambs; these significantly differed from both ARM2 and TRM1 lambs $(P<0.05)$. The only exception was live weight at weaning, which was slightly higher in TRM1 lambs than in TRM0 lambs. Both values significantly differed from live weight at weaning in ARM2 lambs.

Table 5. Lamb growth traits from birth to weaning in dependence on lamb rearing system

\begin{tabular}{|c|c|c|c|}
\hline \multirow[b]{2}{*}{ Traits } & \multicolumn{3}{|c|}{ Lamb rearing system } \\
\hline & $\begin{array}{l}\text { ARM21 } \\
(n=39)\end{array}$ & $\begin{array}{l}\text { TRM12 }^{2} \\
(n=57)\end{array}$ & $\begin{array}{l}\text { TRMO }^{3} \\
(n=56)\end{array}$ \\
\hline \multicolumn{4}{|l|}{ Live weight at } \\
\hline birth, $\mathrm{kg}$ & $4.40 \pm 0.09$ & $4.11 \pm 0.09$ & $4.16 \pm 0.08$ \\
\hline 10 days, $\mathrm{kg}$ & $7.58 \pm 0.20$ & $7.52 \pm 0.16$ & $7.52 \pm 0.17$ \\
\hline 20 days, $\mathrm{kg}$ & $10.60 \pm 0.31^{a}$ & $10.77 \pm 0.25^{\mathrm{a}}$ & $11.12 \pm 0.24^{b}$ \\
\hline 30 days, $\mathrm{kg}$ & $13.63 \pm 0.40^{a}$ & $13.46 \pm 0.33^{a}$ & $14.49 \pm 0.32^{b}$ \\
\hline 40 days, $\mathrm{kg}$ & $16.90 \pm 0.43$ & $16.77 \pm 0.35$ & $17.07 \pm 0.34$ \\
\hline weaning, $\mathrm{kg}$ & $17.97 \pm 0.53^{a}$ & $19.42 \pm 0.43^{b}$ & $19.33 \pm 0.42^{b}$ \\
\hline Age at weaning, days & $50.00 \pm 0.61^{\mathrm{a}}$ & $55.00 \pm 0.49^{b}$ & $58.00 \pm 0.48^{b}$ \\
\hline $\begin{array}{l}\text { Average daily gain from } \\
\text { birth to weaning, } \mathrm{kg}\end{array}$ & $0.259 \pm 0.008$ & $0.260 \pm 0.007$ & $0.277 \pm 0.006$ \\
\hline $\begin{array}{l}\text { Live weight extrapolated } \\
\text { to day } 55, \mathrm{~kg}\end{array}$ & $19.27 \pm 0.53$ & $19.42 \pm 0.43$ & $18.50 \pm 0.42$ \\
\hline
\end{tabular}

\section{Discussion}

\section{Milk yield and milk composition traits}

Findings about higher total commercial milk yield stated in ARM2 and TRM1 ewes than in TRM0 ewes were in accordance with reports of Gargouri et al. (1993), McKusick et al. (2001) and Dikmen et al. (2007). McKusick et al. (2001) reported total milk yields higher in East Friesian ewes milked twice daily throughout a whole lactation $(260.1 \mathrm{~kg})$ than either in ewes milked once daily in preweaning period $(235.8 \mathrm{~kg})$ or in ewes not milked in pre-weaning period $(171.7 \mathrm{~kg})$; thus TRM1 and TRM 0 ewes produced 66 and $73 \%$ of commercial milk yield of ARM2 ewes. Gargouri et al. (1993) reported that total milk yield in TRM1 Manchega ewes was by $27 \%$ higher than in TRM0 ewes (i.e., 110.8 vs 80.8 1). Dikmen et al. (2007) reported that total milk yield in TRM1 Awassi ewes was by $28 \%$ higher than in TRM0 ewes (i.e., $103.3 \mathrm{vs} 63.59 \mathrm{~kg}$ ). Although differences in milk yields between ARM2 and TRM1 ewes are largely due to differences in milking frequency in early lactation, McKusick et al. (2001) indicated that these may be in part explained by inhibition of milk ejection during machine milking. This fact results from a lack of a proper signal which is only present when ewes are suckled by their lambs. In other situations, oxytocin release and milk ejection reflex are inhibited (Marnet and Negrão, 2000). Findings about lower fat percentage (and fat yield) in TRM1 ewes than in ARM2 ewes agree with Labussière et al. (1969), who reported that about $25 \%$ of fat is present in the cisternal milk fraction, while remaining fat remains in the alveolar milk fraction and is at disposal only after an active myoepithelial action has been taken out (Dikmen et al., 2007). According to McKusick et al. (2001) and Dikmen et al. (2007), fat stored in alveoli contributes to early lamb growth. The authors indicated that a lack of milk fat transfer to the cistern during machine milking could be a result of stress which increases when lambs are partially separated from ewes. Thomas et al. (2001) reported that ewes of this mixed treatment experienced impairment of both oxytocin release and milk ejection reflex because they expected that after milking they would be reunited with their lambs. Consequently, milking machine captured their cisternal milk but not alveolar milk, in which most of fat is present. Papachristoforou (1990) reported that Chios ewes suckled by their lambs showed some ability to withhold a certain amount of milk which is released only when ewes are stimulated by the presence of lambs. This author studied fat percentages in ewes of various lamb rearing systems between day 43 and day 77 after parturition; these were found higher in machine milked ewes permanently separated from their lambs than in machined (or hand) milked ewes suckled by their lambs for 5 to $10 \mathrm{~min}$, having audiovisual (i.e., no direct) contact with offspring. In his experiment, all lambs were allowed to suckle ewes for first 29 days of age and stay with ewes for eight hours between 29 and 42 days of age. Significant differences in fat yield between alveolar and cistern milk were reported by McKusick et al. (2002) when investigating ARM2 and TRM1 ewes in first six weeks of lactation.

Trends in daily milk yields and fat percentages over lactation found in this study agree with findings of McKusick et al. (2001) who also reported significantly different daily milk yields and fat percentages mainly in pre-weaning period. Trends in SCS showed less differences between ARM2 and TRM1 ewes in pre-weaning period when results 
of the present study were compared with study of McKusick et al. (2001). However, trends in protein percentages showed more differences between ARM2 and TRM1 ewes in pre-weaning period when results of the present study were compared with study of McKusick et al. (2001). Almost all differences in daily milk yield, fat and protein percentages as well as in SCS were found not significant in post-weaning period when all ewes were milked in the same way (in spite of fact that Slovak Dairy breed lambs were weaned later than East Friesian breed lambs).

When comparing trends in lactose percentages between ARM2 and TRM1 ewes (in pre-weaning period), these are not in agreement with expectations due to fact that higher lactose percentages corresponded with lower daily milk yields, not vice versa. After weaning, almost all differences in studied traits were found not significant in dependence on lamb rearing system. The only exception was day 73 when TRM1 ewes significantly differed from ARM2 ewes in daily milk yield and protein percentage $(P<0.05)$. Lactose percentages varied to greater extent, significant differences $(P<0.05)$ were found in favour of ARM2 ewes (compared to TRM1 ewes) at 136, 164 and 192 day, respectively. To authors' best knowledge, no studies investigating the effect of lamb rearing system on lactose percentages over individual days in milk currently exist in the literature; therefore, respective comparisons could not be carried out.

\section{Lamb growth traits}

Some benefits in terms of lamb growth intensity (Papachristoforou, 1990) in mixed treatment was reported, nevertheless, extra labour involved and stress on mother/offspring of joining and separating, together with an effect on milk fat should be taken into account when deciding whether this treatment is introduced. Peters and Heaney (1974) reported that difference between weights of lambs not separated from ewes and lambs separated from ewes at age of 35 days was significant (i.e., not separated lambs made better gains at early life than separated lambs). McKusick et al. (2001), however, reported no significant difference in live weights and average daily gains of lambs at weaning (i.e., in 30-day old lambs) among three lamb rearing systems (ARM2, TRM1 and TRM0). In the present study, live weights at weaning differed between ARM2 lambs (at 50 days of age) and both TRM1 and TRM0 lambs (at 55 and 58 days of age, respectively), while average daily gains from birth to weaning appeared not to be of significant difference. Significant differences in live weights were probably a result of fact that ages at weaning in TRM1 and TRM0 lambs were significantly higher than age at weaning in ARM2 lambs. When live weights were adjusted at 55 days of age, differences diminished.

The findings of the present study indicate that lamb growth traits are almost the same in three lamb rearing systems and along with more milk which can be sold when ewes are once daily milked in preweaning period; TRM1 lamb rearing system may be considered as more appropriate (although concern on lower fat should be taken into account). McKusick et al. (2001), who in addition to analyses of ewe milk and lamb growth traits performed economic evaluations of lamb rearing systems, also preferred mixed system due to fact that additional labour and supplies associated with artificial rearing absorbed almost all financial advantages of exclusive machine milking. In contrast, TRM1 system showed some increase in profitability when comparing to TRM0 one. This may be taken into account when decisions on lamb rearing systems in Slovak Dairy sheep breed are made.

\section{Conclusions}

With respect to negligible impact on lamb growth and taking into account that milk yield was the second highest, lamb rearing system which enables ewes to be once daily milked in pre-weaning period provided more milk to sell or to use for cheese processing. Such system may be recommended as the most appropriate for Slovak Dairy sheep. The only limitation, which remains unsolved and which is similar to findings from similar experiments with various sheep breeds worldwide, is the low milk fat content found in pre-weaning period. Further effort needs to be done when facing this shortcoming.

\section{Acknowledgement}

The study was supported by the projects VEGA 1/0364/15, KEGA 015SPU-4/2019 and KEGA 035SPU-4/2015. The article was possible through the project APVV-15-0072.

\section{References}

Antonič J., Tančin V., Uhrinčat' M., Mačuhová L., Mačuhová J., Jackuliaková L., 2013. The effect of exogenous oxytocin on milkability and milk composition in ewes differed in milk flow pattern. Small Rumin. Res. 113, 254-257, https://doi. org/10.1016/j.smallrumres.2013.03.011

Barillet F., Rupp R., Mignon-Grasteau S., Astruc J.-M., Jacquin M., 2001. Genetic analysis for mastitis resistance and milk somatic cell score in French Lacaune dairy sheep. Genet. Sel. Evol. 33, 397, https://doi.org/10.1051/gse:2001124 
Dikmen S., Turkmen I.I., Ustuner H., Alpay F., Balci F., Petek M., Ogan M., 2007. Effect of weaning system on lamb growth and commercial milk production of Awassi dairy sheep. Czech J. Anim. Sci. 52, 70-76, https://doi.org/10.17221/2357-CJAS

Folman Y., Volcani R., Eyal E., 1966. Mother-offspring relationships in Awassi sheep. I: The effect of different suckling regimes and time of weaning on the lactation curve and milk yield in dairy flocks. J. Agric. Sci. (Camb.) 67, 359-368, https://doi. org/10.1017/S0021859600017366

Gargouri A., Caja G., Such X., Ferret A., Casals R., Peris S., 1993. Evaluation of a mixed system of milking and suckling in Manchega dairy ewes. In: Proceedings of the $5^{\text {th }}$ International Symposium on Machine Milking of Small Ruminants. Hungarian J. Anim. Prod. 1993, Suppl. 1, 484-499

ICAR, 2014. ICAR Recording Guidelines. Available from: www.icar.org

Knight T.W., Atkinson D.S., Haack N.A., Palmer C.R., Rowland K.H., 1993. Effects of suckling regime on lamb growth rates and milk yields of Dorset ewes. N. Z. J. Agric. Res. 36, 215-222, https://doi.org/10.1080/00288233.1993.10417756

Krupová Z., Krupa E., Wolfová M., Michaličková M., 2014. Impact of variation in production traits, inputs costs and product prices on profitability in multi-purpose sheep. Spanish J. Agric. Res. 12, 902-912, https://doi.org/10.5424/sjar/2014124-6166

Labussière J., Combaud J.-F., Petrequin P., Tessonnière R., Gouget R., 1969. Amount, composition and significance of various milk fractions successively obtained during the mechanical milking of ewes. (in French: Importance, composition et signification des différentes fractions de lait obtenues successivement au cours de la traite mécaniques des brebis). Ann. Zootech. 18, 185-196, https://doi.org/10.1051/animres:19690206

Mačuhová L., Tančin V., Uhrinčat' M., Mačuhová J., 2012. The level of udder emptying and milk flow stability in Tsigai, Improved Valachian, and Lacaune ewes during machine milking. Czech J. Anim. Sci. 57, 240-247, https://doi.org/10.17221/5922CJAS

Margetín M., Čapistrák A., Valkovský P., Kališ M., 1995. Dependence between growth intensity in lambs and milk production in mothers during suckling period. J. Farm. Anim. Sci. 28, 219-225

Margetín M., Čapistrák A., Špánik J., Foltys V., 1996. Somatic cells in sheep milk in relation to milk production and composition during sucking and milking. Czech J. Anim. Sci. 41, 543-550

Margetín M., Debrecéni O., Čapistrák A., Špánik J., Apolen D., Gálisová M., Oravcová M., 2010. Behaviour and growth intensity of dairy sheep lambs raised in nurseries. Slovak J. Anim. Sci. 43, 88-94

Margetín M., Milerski M., Apolen D., Čapistrák A., Oravcová M., Debreceni O., 2013a. Relationships between production, quality of milk and udder health status of ewes during machine milking. J. Central Eur. Agric. 14, 328-340, https:// doi.org/10.5513/JCEA01/14.1.1203
Margetín M., Oravcová M., Makovický P., Apolen D., Debrecéni O., 2013b. Milkability of Improved Valachian, Tsigai and Lacaune purebred and crossbred ewes. Slovak J. Anim. Sci. 46, 100-109

Margetín M., Oravcová M., Huba J., Janíček M., 2017. Formation and characterization of Slovak Dairy composite sheep breed: Description of the process: A review. Slovak J. Anim Sci. 50, 139-143

Marnet P.-G., Negrão J.A., 2000. The effect of a mixed-management system on the release of oxytocin, prolactin, and cortisol in ewes during suckling and machine milking. Reprod. Nutr. Dev. 40, 271-281, https://doi.org/10.1051/rnd:2000131

Marnet P.G., McKusick B.C., 2001. Regulation of milk ejection and milkability in small ruminants. Livest. Prod. Sci. 70, 125-133, https://doi.org/10.1016/S0301-6226(01)00205-6

McKusick B.C., Thomas D.L., Berger Y.M., 2001. Effect of weaning system on commercial milk production and lamb growth of East Friesian dairy sheep. J. Dairy Sci. 84, 1660-1668, https://doi.org/10.3168/jds.S0022-0302(01)74601-2

McKusick B.C., Thomas D.L., Romero J.E., Marnet P.G., 2002. Effect of weaning system on milk composition and distribution of milk fat within the udder of East Friesian dairy ewes. J. Dairy Sci. 85, 2521-2528, https://doi.org/10.3168/jds.S00220302(02)74335-X

Oravcová M., Groeneveld E., Kovač M., Peškovičová D., Margetín M., 2005. Estimation of genetic and environmental parameters of milk production traits in Slovak purebred sheep using test day model. Small Rumin. Res. 56, 113-120, https://doi. org/10.1016/j.smallrumres.2004.03.002

Oravcová M., Margetín M., Tančin V., 2015. The effect of stage of lactation on daily milk yield, and milk fat and protein content in Tsigai and Improved Valachian ewes. Mljekarstvo 65, 48-56, https://doi.org/10.15567/mljekarstvo.2015.0107

Papachristoforou C., 1990. The effects of milking method and postmilking suckling on ewe milk production and lamb growth. Ann. Zootech. 39, 1-8, https://doi.org/10.1051/animres:19900101

Peters H.F., Heaney D.P., 1974. Factors influencing the growth of lambs reared artificially or with their dams. Can. J. Anim. Sci. 54, 9-18, https://doi.org/10.4141/cjas74-002

SAS Institute Inc., 2009. SAS/STAT® 9.2 User's Guide, Second Edition. Cary, NC (USA)

Thomas D.L., Berger Y.M., McKusick B.C., 2001. Effects of breed, management system, and nutrition on milk yield and milk composition of dairy sheep. J. Anim. Sci. 79, Suppl. E, E16-E20, https://doi.org/10.2527/jas2001.79E-SupplE16x

Thomas D.L., Berger Y.M., McKusick B.C., Mikolayunas C.M., 2014. Dairy sheep production research at the University of Wisconsin-Madison, USA - a review. J. Anim. Sci. Biotechnol. 5, 22, https://doi.org/10.1186/2049-1891-5-22 